\title{
De-Colonising Shakespeare?: Agency and (Masculine) Authority in Gregory Rogers's The Boy, The Bear, The Baron, The Bard
}

\author{
Erica Hateley
}

Underlying social space are territories, lands, geographical domains, the actual geographical underpinnings of the imperial, and also the cultural contest. To think about distant places, to colonize them, to populate or depopulate them: all of this occurs on, about, or because of land. [...] Imperialism and the culture associated with it affirm both the primacy of geography and an ideology about control of territory.

(Said 1994, p.78)

Although Said is writing about literal geographies here as well as cultural mappings of them, I open with his claims in order to initiate my consideration of the ways in which 'Shakespeare' as a discourse (Freedman 1989, p.245) and Shakespeare's historical and geographical contexts have been made over into culturally-contested terrain within contemporary children's literature for the purposes of constructing and controlling social space and subjectivities. Historically, both the discourse of 'Shakespeare' and the depiction of William Shakespeare as a character have been deployed as structuring logics for narratives about the inherent value of Shakespeare, and in turn, for discussions of not just the legitimacy but the necessity of young people's subordination of self to Shakespeare. Gregory Rogers's The Boy, The Bear, The Baron, The Bard (2004) not only participates in that tradition of children's literature which deploys Shakespeare as a colonising discourse but also disrupts the norms of the tradition in two important ways. First, where boy-meets-Shakespeare narratives privilege a paternal Shakespeare (father to Western culture, father to boys) and identify Shakespeare's value through his linguistic mastery, Rogers offers a wordless Shakespeare. Second, he depicts a boy succeeding by evading William Shakespeare. In doing so, Rogers makes an ironic intervention into a genre that is itself inherently ironic, and by multiplying ironic levels of meaning opens up a space for child readers to consider themselves as agents within or without reference to (at least some) existing social and cultural hierarchies. Although these are both important strategies, the book nonetheless rests on a gendered logic of masculine agency and feminine passivity as embodied by William Shakespeare and Elizabeth I: present here as figures of adult cultural authority with whom the child protagonist must engage in order to succeed. Thus, even as a case can be made for the book revising dominant understandings of Shakespeare as a figure of cultural authority and even of cultural paternity, I argue that it does not challenge the patriarchal ideology with which colonial logics have historically intertwined, and which structure understandings of Shakespeare as a cultural father figure.

\section{Boy-Meets-Shakespeare Plot: De/colonising strategies}

Rogers's surface narrative of challenging Shakespeare's cultural authority make sense for a contemporary (perceivably postcolonial) Australian child-readership, insofar as, 'The adaptation and re-interpretation of the earlier Old World literature of colonization, i.e., The Tempest, as literature of decolonization is [...] at its best, superior in effectiveness to an anticolonial polemic $[\ldots]$ it constitutes one of the most cogent strategies of decolonization in literature' (Zabus 1985, p.49). This makes sense in the context of a long history of adaptations and appropriations of Shakespeare's works for global, adult audiences, but is a little more problematic in 
the context of children's literature. In fact, the offering of Shakespeare to young readers is in general a vexed enterprise: there can be no guarantee that a child reader will have a preexisting knowledge of Shakespeare, and so authors must often provide the very cultural competency they wish to critique. Further, Shakespeare is valued notionally for his mastery of and over the English language, but such complex linguistic features as those found in Shakespeare's writings are seen as too difficult for young or beginning readers. Janet Bottoms notes that, 'the plots, previously criticized by scholars as Shakespeare's weakest point, have come to be seen as valuable in themselves because they are his' (Bottoms 2000, p.17), that is, they are useful to children's writers because they present less linguistic difficulty than Shakespeare's own verse. Nonetheless, given the socialising and acculturating project of children's literature as a genre, and the cultural capital of Shakespeare, there is an unsurprisingly long history of producing Shakespearean texts for young people that do not critique or even question the cultural authority of 'Shakespeare'. Despite its catchy, alliterative title, The Boy, The Bear, The Baron, The Bard is a picture book that does not engage with Shakespeare's plots, and because it is wordless - cannot engage with Shakespeare's language, and thus simultaneously evokes and undermines what has evolved into a relatively stable boymeets-Shakespeare plot.

This plot operates most often in historical or timeslip texts, wherein a young person (usually a boy) comes into contact with the 'real' William Shakespeare in his own time. Examples of the boy-meets-Shakespeare plot can be found in novels such as Geoffrey Trease's 1940 classic, Cue for Treason, J. B. Cheaney's The Playmaker (2000) and The True Prince (2002), and Gary Blackwood's more recent trilogy of novels, The Shakespeare Stealer (1998), Shakespeare's Scribe (2000) and Shakespeare's Spy (2003). The boy protagonists of these novels usually instinctively register Shakespeare's genius, work hard-most often as a playhouse apprentice-and build a pseudo-filial relationship with Shakespeare, who in turn becomes a willing father-figure to said boy. The cultural logic of such trajectories, obviously, is that contemporary child readers can gain paternal wisdom and support from the plays Shakespeare left behind; or in other words, we can all be Shakespeare's children if we read the 'right' way. The implied child readers have modelled for them an example of relating to Shakespeare which on the surface appears to affirm individual development, but which actually deploys a colonial logic of subjection of the self to a broader cultural authority. In keeping with boy-meetsShakespeare narrative tradition, Rogers's protagonist travels to Elizabethan London and encounters Shakespeare, but in contrast with earlier incarnations of the plot, not only does not form a bond with the playwright but actually encounters him as a threat. Boymeets-Shakespeare texts draw on dominant understandings both of childhood and of Shakespeare in popular culture. Not coincidentally, each of these has been characterised by and through colonising logics. As Loomba and Orkin note:

Shakespeare lived and wrote at a time when English mercantile and colonial enterprises were just germinating. [...] four hundred years later, both Shakespeare and colonialism have left their imprint on cultures across the globe. [... and] colonial educationists and administrators used [...] Shakespeare to reinforce cultural and racial hierarchies. Shakespeare was made to perform such ideological work both by interpreting his plays in highly conservative ways (so that they were seen as endorsing existing racial, gender and other hierarchies, never as questioning or destabilizing them) and by constructing him as one of the best, if not 'the best', writer in the whole world. He became, during the colonial period, the quintessence of Englishness and a measure of humanity itself. Thus the 
meanings of Shakespeare's plays were both derived from and used to establish colonial authority.

(Loomba and Orkin 1998, p.1)

As with the irony of offering Shakespeare's plots to children, we see here another irony of Shakespearean appropriation: at the same time as Shakespeare is made over into a tool of Colonialism, the works of Shakespeare themselves are ideologically colonised. In turn, child readers are colonised in the sense that they are inducted into a cultural hierarchy. Glancing back at Said's claims about control of territory, there are thus multiple ironic intersections between Shakespeare as territory and tool of territorialisation, children's literature as territory and tool of territorialisation, and Shakespearean children's literature as combining all of these elements.

It is true and right that conceptions of the reader implied by children's literature as potentially or actually colonised subject have been contested within children's literature studies. Those critics too ready to see the real child reader coalescing seamlessly with the implied child reader leave themselves open to the accusation of over-simplifying reading processes and effects, and perhaps more saliently, to the charge of viewing children as passive, acquiescent 'empty vessels'. Nonetheless, and bearing in mind certain (albeit problematic) assumptions about childhood being a territory of colonisation undertaken by adult culture, it is no great surprise, that within the genre of Shakespearean children's literature, such logics are prevalent, not only in terms of implied readership but also in diegetic representations of children forming interpersonal relationships with William Shakespeare. There are a number of works which not only thematise, but consciously or not depend on, visions of Shakespeare and childhood bound up within precisely those colonial ideologies identified by Loomba and Orkin. Hence Douglas Lanier notes:
It's commonly claimed that these kinds of works [predominantly televisual] entertainingly introduce children to Shakespearian plots and language, preparing them for serious study later on. While this is true, we should notice that they also introduce children to hierarchies of taste and position Shakespeare firmly as an elitist icon with mass culture as his popular, comic, anarchic Other. But to rest on this point is potentially misleading. We should also recognize that by virtue of being members of a society, children, like their adult counterparts, are always already enmeshed in a system of cultural hierarchies not of their own making, one in which Shakespeare is already encoded as high culture.

(Lanier 2002, p.108)

It is such a Colonising/Paternal Shakespeare - the playwright as unique, inspirational, genius role-model-against whom or which Rogers's picture book attempts to work. That said, Rogers's seeming critique of Shakespearean value can really only be recognized by readers already at least somewhat versed in this value; in turn, this necessary irony maps onto a tension between Rogers's arguably decolonising gestures and the necessarily colonising implications of the boy-meetsShakespeare plot. Despite cogent critiques of 'child as colonised subject' then, I am nonetheless drawing on Roderick McGillis's points about the broad ironies of asserting decolonising logics within children's literature:

When we bring ideas of liberation and decolonization to the subject of children and their literature, the irony ought to be evident: children continue to be the subaltern and their literature continues to serve as a colonizing (socializing, taming, wrecking-all these words have appeared in works about children and their literature) agent par excellence. But I need to note a farther irony. I speak of 
the irony of knowing, or what Richard

Rorty calls "knowingness".

(McGillis 2000, p.224)

Such knowingness is indeed the irony not only of Shakespeare for children, but also the irony that Nodelman attributes to picture books as a genre:

Irony occurs in literature when we know something more and something different from what we are being told. We are aware that the words we are reading are incomplete. Something similar happens when we interpret a picture ironically; we believe we know more and different information from what the picture shows us.

(Nodelman 1988, p.223)

With such complication, and competing and complementary ironies as those produced when combining "Shakespeare" (plots vs. language), children's literature (colonising vs. non-colonising), and picture books (known vs. unknown), within a wordless picture book "about" a boy's encounter with William Shakespeare, the production and reading of such a text is clearly a complex, and perhaps inescapably ironic, project. That is, where this text is activating a decolonising cultural critique, this activation is complicated by the necessity of Shakespearean knowledge to recognizing such a critique, and is further complicated by tensions between the book's cultural politics and its gendered politics.

\section{The Boy, The Bear, The Baron, The Bard and Childhood Agency}

The most cursory of readings shows the centrality of Shakespeare to Rogers's picture book, even as it simultaneously demonstrates that this is a story of childhood agency available to all readers, regardless of whether said readers have cultural competencies in "Shakespeare". Briefly, in The Boy, The Bear, The Baron, The Bard, a young boy of contemporary London pursues a lost football into an empty theatre. Once there, he dresses up in abandoned costume and steps through the curtain to find himself in the Globe Theatre over four centuries earlier. To quote one reviewer's summary:

\section{His appearance mid-performance} disrupts the play and angers the playwright (who seems to be William Shakespeare), so he flees the theater and acquires a companion when he frees a caged bear; boy and bear cross the bridge to the north of the river, where they free a prisoner, the titular baron, from the Tower, and then return to the river, where they meet the queen on her royal barge and engage in a frolic. Still pursued by the playwright, the boy heads back to the now-darkened theater, where he narrowly escapes the irate Shakespeare by returning to his own time.

(Stevenson 2004, pp.182-183)

Although the text is wordless, its narrative is clearly indicated by the book's illustrations, which follow a top-to-bottom, left-to-right pattern as do most English-language texts. Reader identification is initially produced by the fact that the boy is the only character who appears in the story's early action (even though Shakespeare has already appeared on the endpaper), and is shown engaging in stereotypical childhood physical play and pretence. Reader identification is produced and sustained by continuing visual and narrative focus on the boy, as well as by inviting readers to share his child's-eye perspective on the world in which he finds himself.

The absence of language, and the powerful effects of such absence, are highlighted if Rogers's book is compared with Marcia Williams's Mr. William Shakespeare's Plays (1998) and Bravo, Mr. William Shakespeare! (2000) both of which successfully integrate images of plays in performance and their audiences, and language drawn directly from Shakespeare's plays as well as audience commentaries. The effect of these multiple strands in Williams's picture books makes for an entertaining and educational read, but 
although the child reader is interpellated as an intelligent and independent reader by Williams, she cannot reproduce the performance and language spaces of the Globe theatre and have a sustained figure of identification for that reader. Williams's readers are clearly outside the book whereas Rogers invites his readers into the book offering them emotional and narrative modes of identification. As Perry Nodelman points out, 'Because [wordless] books have no words to focus our attention on their meaningful or important narrative details, they require from us both close attention and a wide knowledge of the visual conventions that must be attended to before visual images can imply stories' (Nodelman 1988, p.186). Therefore, presuming a reader with competence in normative Western visual/narrative conventions, this picture book offers a story of and about childhood agency whereby the protagonist undertakes independent movement/action, and the child reader is invited to undertake independent meaning-making.

The book's images vary in their composition with regard to layout, point of view, perspective, implied movement etc. Images work at different points in the book to manipulate time and space in different ways, showing that Rogers's comment about 'illustration working as literature' is borne out by this book. Point of view is manipulated in various ways throughout the text, and is exemplified by the images depicting the boy's arrival on-stage at the Globe. Readers are offered a view of the Globe's audience from the boy's point of view. This image is immediately followed by a reversal, showing the audience's point of view of the boy on stage. Thus readers are encouraged to be conscious of viewing and being viewed, and even as they are invited to identify with the boy and his curiosity about the world he finds himself in, are also visually reminded that the boy himself is also an object of curiosity in this world. The book depends on readers' recognition of the boy, and possibly themselves, as both subject and object.
This balance and tension between individualism and environment, between subjectivity and objectivity, appear in a variety of ways throughout The Boy, The Bear, The Baron, The Bard wherein Rogers offers openings which variously focus on fullbleed landscape/environment images, and white-space montages of people dancing in any or no environment. In one full-bleed opening, readers are given a bird's-eye view of Tower Bridge, and although they may notice that witches are rowing on the Thames (a nod, perhaps, to Shakespeare's Macbeth, anachronistic as this is, given Elizabeth's presence in the book), the image emphasises the foreignness of this environment for the boy and for readers. In juxtaposition with this environmental focus, another opening, this with a full-bleed white background, shows Elizabeth's court at play, inviting readers to focus on bodies and community, or at least social relations. Indeed, readers are arguably invited to see the similarities between children and adults on this latter opening, whereas earlier the book clearly differentiated between the two groups, at least in the boy's experience of arriving at the Globe. William Moebius tells us that, 'The more frequently the same character is depicted on the same page, the less likely that character is to be in control of a situation' (Moebius 1986, p.149), but Rogers both affirms and denies this claim: the reverse $S$-shape of the images depicts the boy and the bear's integration into the social elite, even as that elite is shown to be childish (or at least out of control). They also offer a kind of revisionist historical account insofar as the three 'processions' depict a burgeoning romance for Elizabeth; she is shown three times, and may exercise social control, but does not necessarily have self control.

Unsurprisingly, given that The Boy, The Bear, The Baron, The Bard is a timeslip story, Rogers plays with representations of temporality as much as he does with people and places. Thus, one image (an exploding clock) is devoted to the boy's slide through four centuries. As the boy is about to return to his own time, however, several images are 
devoted to a split-second during which Shakespeare only narrowly misses grasping the boy's cloak. I point out these temporal strategies because:

All cultural paradigms [...] can be characterized in terms of their specific mode of organization of time and space. They can be characterized in terms of $(a)$ how time and space are organized and (b) in terms of what imparts organization to time and space.

(Abercrombie, Lash and Longhurst 1992, p.119)

Rogers's production of time and space is innovative within the context of Shakespearean children's literature insofar as it achieved entirely through visual images, and works to maintain distance between Shakespeare and the protagonist. Nonetheless, 'what' imparts organisation to the narrative is the cultural value and authority of Shakespeare. Thus, even as The Boy, The Bear, The Baron, The Bard invites and facilitates a readerly pleasure independent of 'Shakespeare', in order to engage fully with the book's cultural politics, its Shakespearean aspects must be taken account of. It is possible, rather than probable, that the child reader of Rogers's text will have the historical, cultural, or literary/generic knowledge to understand all of the ironic gestures made by The Boy, The Bear, The Baron, The Bard. Given this fact, the book as a whole becomes an ironic entry into a genre that is itself fundamentally ironic: Shakespeare for children. The adult mediators of the genre-authors, editors, publishers, booksellers, librarians, parents, teachers, etc.- knowingly (if not necessarily consciously) thus withhold information from child readers at the very moment of seeming to provide it. That is, in the proffering of Shakespeare as entertainment, we mask the instrumentality of Shakespeare as education and/or capital. We do not disclose the centuries-long process of making Shakespeare exclusive, superior, canonical, colonial, and of the production of Shakespeare as marker of socio-cultural legitimacy. We do not disclose the history that renders The Boy, The Bear, The Baron, The Bard simultaneously playful about, and participatory in, the project of socialisation and acculturation endemic to the production of Shakespeare for children.

The extent to which Rogers seems to privilege a pleasurable, entertaining experience over an educational one, particularly when compared with Williams's books, is indicated by the relatively straightforward point that even as The Boy, The Bear, The Baron, The Bard delineates a very clear narrative drive, no specific historical knowledge is necessary in order to understand this narrative. That said, if one is familiar even in the most general way with popular tropes of Elizabethan London and its two most notorious residents-Queen Elizabeth I and William Shakespeare-the narrative would also seem to have a specific symbolic drive. But herein lies a problem: for Rogers to mobilise a decolonising critique, the colonial must be recognized, taken account of, known.. Whether the Shakespearean or the colonial is known or not, this is a remarkable story of childhood (and implied readerly) agency. That the boy moves into or through the playhouse, the prison, the palatial barge, and repeatedly not merely gestures towards, but literally liberates confined subjects indicates a reversal of the logics which identify children as subjects to be acted upon by adult culture. In this picture book, a child not only refuses to be acted upon, but also rescues others from the same plight, undoing the physical confinement of the bear and the baron, and even initiating a romance for the 'Virgin Queen'. Nonetheless, violent and/or physically threatening images of Shakespeare such as those offered by Rogers are highly unusual in children's fiction, or indeed, in popular culture generally, and are thus important. When readers see Shakespeare scowling at, apparently attempting to throttle, and constantly pursuing the boy it is made clear that this is no father-figure Shakespeare (or, at least, no benign paternal Shakespeare). In fact, this Shakespeare seems devoted to curbing rather than developing the boy's abilities or independence. Further, if we know 
what bear baiting is; if we know that the most common reason for being imprisoned in the Tower was treason; if we know who William Shakespeare was and 'is'; this book is an impressive complication of the genre of Shakespeare for children. The boy's transgressive movement through the social and geographic spaces of late sixteenthcentury London mobilises a kind of decolonising critique of the logics Said attributed to Imperial spaces and territories, which serves to dislocate Shakespearean authority, and disrupt teleologies of Shakespeare and Empire in favour of childhood agency. Indeed, if we are to believe the endpapers, Shakespeare has been changed by this encounter more than the boy has. Where the opening endpapers depict a portrait of a startled but noble Shakespeare meeting the reader's gaze, and with a coat of arms in the background, the closing endpapers repeat this image with the difference that Shakespeare now appears tousled, holds a football under his arm, and is evading the reader's gaze as he glares stage left. Even as Rogers is (necessarily) implicated in the very Shakespearean discourses he is complicating, or even challenging, the most important gesture he makes is to reward child readers with a sense of agency rather than passive subjection to the discourse of Shakespeare.

The wordlessness of the text extends this logic of juvenile agency to readers: this story is available to child reader of full or no linguistic literacy. Just as the boy evades adult intervention in his life, so might readers evade the normative reading experience attached to picture books. Nikolajeva notes that 'Picturebooks, more than any other kind of children's literature, are read and appreciated by children and adults together, most often with the adult reading the book to a child or group of children' (Nikolajeva 2003, p.243). Pointing out the ideological functions of such reading situations, Parsons more explicitly argues:

picture books can be understood as complicit with typical reading situations. Such situations commonly entail an adult/older reader who has some level of

\begin{abstract}
authority over child listeners, particularly the intellectual authority conferred by the ability to read (which younger children, who are most often the audience for picture books, either lack or are in the process of learning). This disparity confers some of the reader's authority onto the story itself because the words are, as child audiences experience the performance, being spoken by the adult figure and are thus arguably endorsed by them.
\end{abstract}

(Parsons 2004, n.p.)

Hence, the potential correlation between the eponymous boy's avoidance of Shakespeare and the reader's avoidance of the social and ideological authority of a mediating adult reader, means that while Rogers critiques adult culture via his Shakespearean content and context, child readers are potentially left free to accept or reject such cultural codings. Such an interpretation of The Boy, The Bear, The Baron, The Bard is liberating-for child and adult readers-even as the fact of adult production and circulation of the text might render such a liberatory reading illusory.

Nonetheless, whether child readers are left to make and unmake meanings within and about the book themselves, encoded in the text are a number of ideological representations or assumptions that ought to give critical readers of any age pause. The book's opening images of an abandoned proscenium theatre-images which juxtapose powerfully with the lively images of the Elizabethan thrust-stage theatre-indicate a kind of mourning for live theatre in contemporary culture. Overall, it must be said, The Boy, The Bear, The Baron, The Bard is a book that celebrates performance, costume, disguise, and deception, or in other words, theatre. This is not necessarily problematic, but it does establish a romance of cultural decline that potentially undermines the book's project of desacralising Shakespeare. Similarly, the book mobilises a relatively unproblematic critique of bear baiting and imprisonment (of bears and humans), but the liberation of the 
bear and the baron leads to a disturbing revision of Elizabeth I.

\section{Revisioning Elizabeth I and Shakespeare: Masculine Agency and Gendered Ideology}

On the one hand, Rogers refigures Elizabethan culture as pleasurable when seen to revolve around Elizabeth herself, rather than the threatening tone of Shakespeare's presence. On the other hand, Elizabeth is excluded from both the book's title and its politics of power: the book implies that she falls in love-at-first-sight with the newly liberated baron, and thus she incorporates the boy, the bear, and the baron into her court which here is a place of dancing and games. This particular representation of Elizabeth is as revisionary as the book's representation of Shakespeare, but it revises her in such a way as to dislocate her from political agency: this is not the Elizabeth of history, not the Elizabeth of Tilbury. I name Tilbury specifically here as it is possibly the bestknown Elizabethan 'moment' beyond Elizabethan or English Renaissance Studies. Although the inspection of the troops at Tilbury is probably as mythicised as it is mythic, it nonetheless continues to operate metonymically for contemporary understandings of Elizabeth I as a political and personal force to be reckoned with. As Susan Frye notes, 'examination of these [Tilbury] fictions reveals how they perpetuate the belief in an English first unified under Elizabeth-a belief that constructs Elizabeth I as a personally complex but politically monolithic figure' (Frye 1992, p.96). The book's containment of Elizabeth within a logic of romance and nurturing serves a related but crucially different ideological project from that of the rewriting of Shakespeare. In the latter case, the book charts shifting modes of power and agency as sites of contest between male figures: even as Shakespeare is demonised, he is nonetheless a figure of power. In comparison, Elizabeth is reduced to a fluttering, dancing ninny; her revision serves to further consolidate power as operating amongst or between men. The always-already destabilising presence in any account of Elizabethan England as a patriarchal culture is the Queen herself. Although she certainly worked within inherently patriarchal logics, Elizabeth's emphatically female body always posed a threat to such logics. Rogers's account of Elizabeth simultaneously emphasises stereotypical femininity and de-emphasises her political subjectivity. Thus, although Rogers's revision of Elizabeth is seemingly analogous with his revision of Shakespeare, the radical departure from the Tilbury image of Elizabeth as political agent undertakes quite different cultural work. Whatever else he may be in this text, Shakespeare remains a playwright and thus retains cultural agency where Elizabeth's cultural status is diminished.

Such elements of The Boy, The Bear, The Baron, The Bard, for all of its interventions in the dominant boy-meets-Shakespeare plot of contemporary children's literature (and the cultural paternalism such plots promote) suggest that it nonetheless promulgates the patriarchal ideology that often underpins these plots. As Kate Chedgzoy notes of YA incarnations of the plot:

the fiction of the Shakespeare theatre
company as surrogate family combines
with the emotional investment of Western
culture in the fantasy of Shakespeare
himself as idealized father figure to
produce an uneasy meditation on the
repressions and exclusions of gender and
sexuality that have to be performed in
order to sustain those fantasies.
(Chedgzoy 2007, p.197).

Although Rogers critiques the fantasy of Shakespeare as idealised father figure, he nonetheless would seem to reproduce a problematic vision of gendered ideology in the process. The boy protagonist is, after all, a boy, and much of the book's action centres on social relations between men. The overarching vision of liberation or freedom does not seem to be as universal as one might wish, regardless of the book's production and inculcation of childhood agency. In this sense, 
the text retains a kind of colonising, acculturating, and socialising drive: it does reward agency in relation to Shakespeare, but only to some.

\section{Conclusion}

The fundamental irony of The Boy, The Bear, The Baron, The Bard is less the idea of wordless and non-paternal Shakespeare than the fact that Rogers must deploy the colonising strategies of Shakespearean children's literature generally in order to mobilise a decolonising critique of Shakespearean children's literature. To imagine childhood agency for his protagonist, Rogers must in some sense withhold it from his reader; to critique Shakespearean authority, he must render it ridiculous; and to produce a non-ironic Shakespearean children's text, he must embed himself in discourses characterised first and foremost by competing ironies, not the least of which is an unquestioned patriarchal logic. Presumably, Rogers is conscious of and caught between, both the aesthetic power of Shakespeare's works and of the Imperial and Colonial uses to which those works have been put. But as Richard Burt reminds us: 'Though the production of a new Shakespeare version or citation tends to imagine itself as breaking with the old, with tradition, it also always creates an archive making it continuous with past versions' (Burt 1998, p.20). Therefore, it is not surprising that The Boy, The Bear, The Baron, The Bard aligns with the history of Shakespearean children's literature even as it complicates it. Gregory Rogers's work may be an early-if not the first-example of new ways of offering Shakespeare to child readers, but it nonetheless participates in the cultural project of offering Shakespeare to children.

This book initiates a new critical and cultural conversation about what Shakespeare has meant, and can or should 'mean' when we are thinking about children and their literature, particularly in relation to the colonising uses of people, texts, or ideas saturated with cultural capital. Novelty alone, however, does not negate the necessity of analysis: there still seems to be some distance (be it in space or time) to travel before we fully reimagine children's potential Shakespearean and nonShakespearean agency and authority. If this book is actually about the struggle for control of social and cultural territory, it seems that even when Shakespeare's paternity is questioned, the patriarchal logics that underpin such models are not.

\section{REFERENCES}

Abercrombie, N, Lash, S \& Longhurst, B (1992) 'Popular representation: recasting realism', in S. Lash \& J. Friedman (eds) Modernity and Identity. Oxford, Blackwell, pp.115-140.

Blackwood, G(1998) The Shakespeare Stealer. New York, Dutton Children's Books.

Blackwood, G (2000) Shakespeare's Scribe. New York, Dutton Children's Books.

Blackwood, G (2003) Shakespeare's Spy. New York, Dutton Children's Books.

Bottoms, J (2000) 'Familiar Shakespeare', in E. Bearne \& V. Watson (eds) Where Texts and Children Meet. London, Routledge, pp.11-25.

Burt, R (1998) Unspeakable ShaXXXspeares: Queer Theory \& American Kiddie Culture. New York, St. Martin's.

Cheaney, J. B. (2000) The Playmaker. New York, Dell Yearling.

Cheaney, JB (2002) The True Prince. New York, Dell Yearling.

Chedgzoy, K (2007) 'Shakespeare in the company of boys', in S. Greenhalgh, R. Shaughnessy \& K. Chedgzoy (eds) Shakespeare and Childhood. Cambridge, Cambridge University Press, pp.184-200.

Freedman, B (1989) 'Misrecognizing Shakespeare', in N. Holland, S. Homan \& B. Paris (eds) Shakespeare's Personality. Berkeley, University of California Press, pp.244-260. 
Frye, S (1992) 'The myth of Elizabeth at Tilbury', Sixteenth Century Journal 23, 1: 95-114.

Lanier, D (2002) Shakespeare and Modern Popular Culture. Oxford, Oxford University Press.

Loomba, A. \& M. Orkin, M (1998) 'Introduction: Shakespeare and the post-colonial question', in A. Loomba \& M. Orkin (eds) Post-Colonial Shakespeares. London, Routledge, pp.1-19.

McGillis, R (2000) 'And the Celt knew the Indian': Knowingness, postcolonialism, children's literature', in R. McGillis (ed) Voices of the Other: Children's Literature and the Postcolonial Context. New York, Routledge, pp.223-236.

Moebius, W (1986) 'Introduction to picturebook codes', Word \& Image 2, 2: 141-158.

Nikolajeva, M. (2003) 'Verbal and visual literacy: The role of picturebooks in the reading experience of young children', in N. Hall, J. Lawson \& J Marsh (eds) Handbook of Early Childhood Literacy. London, SAGE, pp.235-248.

Nodelman, P. (1988) Words About Pictures: The Narrative Art of Children's Picture Books. Athens, University of Georgia Press.

Parsons, E. (2004) 'Starring in the intimate space: Picture book narratives and performance semiotics', Image \& Narrative 9 $<$ http://www.imageandnarrative.be/ performance/parsons.htm>.

Rogers, G. (2004) The Boy, The Bear, The Baron, The Bard. Crows Nest, NSW, Allen \& Unwin.

Said, E. (1994) Culture and Imperialism. New York, Vintage.

Stevenson, D (2004) 'The boy, the bear, the baron, the bard', Bulletin of the Center for Children's Books 58, 4: 182-183.
Trease, G(2002) Cuefor Treason. Harmondsworth, Puffin.

Williams, M. (1998) Mr. William Shakespeare's Plays. London, Walker Books.

Williams, M (2000) Bravo, Mr. William Shakespeare! Cambridge, MA, Candlewick.

Zabus, C (1985) 'A Calibanic tempest in anglophone and francophone new world writing', Canadian Literature 104: 35-50.

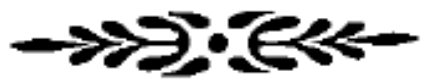

\section{BIOGRAPHICAL NOTE}

Erica Hateley is a lecturer in the School of Cultural and Language Studies in Education at Queensland University of Technology. She is the author of Shakespeare in Children's Literature: Gender and Cultural Capital (Routledge, 2009). 